\title{
Microbispora thailandensis sp. nov., an actinomycete isolated from cave soil
}

\begin{abstract}
Kannika Duangmal ${ }^{1,2}$, Ratchanee Mingma ${ }^{1,2}$, Wasu Pathom-aree ${ }^{3}$, Nanthavut Niyomvong ${ }^{1}$, Yuki Inahashi ${ }^{4}$, Atsuko Matsumoto ${ }^{5}$, Arinthip Thamchaipenet ${ }^{2,6}$ and Yoko Takahashi ${ }^{4,5}$

The taxonomic position of actinomycete strain NN276 ${ }^{\top}$, isolated from cave soil, was studied using the polyphasic taxonomic approach. A phylogenetic tree based on 16S ribosomal RNA (rRNA) gene sequences showed that the isolate formed a distinct evolutionary linage with the genus Microbispora, with $M$. mesophila JCM $3151^{\top}$ as its closest phylogenetic neighbor $(97.9 \%$ similarity). The organism contained meso-diaminopimelic acid and the $\mathrm{N}$-acetyl type of peptidoglycan. Madurose was detected in the whole-cell hydrolasate. The predominant menaquinones were MK-9 $\left(\mathrm{H}_{4}\right), M K-9\left(\mathrm{H}_{2}\right)$ and MK-9. Mycolic acids were not detected. Major phospholipids were diphosphatidylglycerol, hydroxy-phosphatidylethanolamine, phosphatidylethanolamine, phosphatidylinositol and phosphatidylinositol mannoside. The major cellular fatty acid was iso- $\mathbf{C}_{16: 0}$ and $\mathbf{G}+\mathbf{C}$ content $70 \mathrm{~mol} \%$. DNA-DNA hybridization demonstrated that the isolate was distinct from M. mesophila JCM $3151^{\top}$. On the basis of phenotypic and genotypic data, it is proposed that strain NN276 ${ }^{\top}$ represents a novel species of the genus Microbispora, hence the name Microbispora thailandensis sp. nov. The type strain is strain NN276 ${ }^{\top}\left(=\mathrm{BCC}^{2} 41490^{\top}=\mathrm{NRRL} B-24806^{\top}=\mathrm{NBRC}^{\mathrm{N}}\right.$ $\left.107569^{\top}\right)$.

The Journal of Antibiotics (2012) 65, 491-494; doi:10.1038/ja.2012.57; published online 11 July 2012
\end{abstract}

Keywords: actinomycete; cave soil; Microbispora

\section{INTRODUCTION}

The genus Microbispora was proposed for actinomycetes that formed aerial hyphae bearing longitudinal pairs of spores ${ }^{1}$ with $M$. rosea as type species. In 1998, Zhang et al. ${ }^{2}$ reclassified the genus Thermomonospora and proposed to transfer mesophilic actinomycete that produces spores singly borne on aerial hyphae, Thermomonospora mesophila, to M. mesophila owing to their related chemotaxonomic properties and $16 \mathrm{~S}$ ribosomal RNA (rRNA) sequences. The genus Microbispora was then emended with a change in morphological description by having a single spore in the species M. mesophila. The genus Microbispora currently contains five species, namely $M$. amethystogenes, 3,4 M. corallina, ${ }^{5}$ M. mesophila, ${ }^{2,6}$ M. rosea (containing M. chromogenes, $M$. diastatica, $M$. indica, M. karnatakensis, $M$. rosea, which were reduced to a single taxon as $M$. rosea subsp. rosea, and $M$. aerata, M. thermodiastatica and $M$. thermorosea, which were also combined as M. rosea subsp. aerata) $)^{3,4}$ and $M$. siamensis. ${ }^{4}$ Representatives of this genus form a distinct monophyletic group within the evolutionary radiation encompassed in the family Streptosporangiaceae, the family that included the following genera: Acrocarpospora, Herbidospora, Microbispora, Microtetraspora, Nonomuraea, Planobispora, Planomonospora, Planotetraspora, Sphaerisporangium, Streptosporangium and Thermopolyspora. ${ }^{7-9}$ During our investigation of cultivable actinomycetes from tropical limestone caves in Nakorn Sawan province, Thailand, an actinomycete strain, NN276 ${ }^{\mathrm{T}}$, was isolated from cave soil. The present polyphasic study was designed to establish the taxonomic status of the strain. On the basis of polyphasic resultant data, isolate $\mathrm{NN} 276^{\mathrm{T}}$ represents a novel species of the genus Microbispora.

\section{MATERIALS AND METHODS}

Strain $\mathrm{NN}_{276^{\mathrm{T}}}$ was isolated from a soil sample collected from tropical limestone cave. Soil suspension was pretreated with an electromagnetic wave according to a modified method from Bulina et al. ${ }^{10}$ by irradiated soil suspension with the microwave oven at a frequency of $2460 \mathrm{MHz}$ and a power setting of $100 \mathrm{~W}$ for $45 \mathrm{~s}$. The pretreated samples were further diluted with $0.85 \% \mathrm{NaCl}$ solution. One hundred microliters of an appropriate dilution was spread over the surface of humic acid-vitamin (HV) agar ${ }^{11}$ supplemented with nalidixic acid $\left(25 \mu \mathrm{g} \mathrm{ml}^{-1}\right)$ and ketoconazole $\left(100 \mu \mathrm{g} \mathrm{ml}^{-1}\right)$ to inhibit the growth of bacteria and fungi, respectively. Plates were incubated at $28{ }^{\circ} \mathrm{C}$ for 2 weeks. The strain was then purified and maintained on glucose yeast extract (GYE) agar ${ }^{12}$ at room temperature. Suspensions of spores or mycelium were stored in glycerol $(20 \%, \mathrm{v} / \mathrm{v})$ at $-20^{\circ} \mathrm{C}$ and lyophilized for long-term preservation. Cultural characteristics of the strain $\mathrm{NN} 276^{\mathrm{T}}$ were determined using a 14-day culture on ISP media 2, 3, 4, 5 of Shirling and Gottlieb ${ }^{13}$ (Difco, Detroit, MI, USA) and GYE agar at $27^{\circ} \mathrm{C}$. The color of mycelium and the

${ }^{1}$ Department of Microbiology, Kasetsart University, Bangkok, Thailand; ${ }^{2}$ Center for Advanced Studies in Tropical Natural Resources, NRU-KU, Kasetsart University, Bangkok, Thailand; ${ }^{3}$ Department of Biology, Chiang Mai University, Chiang Mai, Thailand; ${ }^{4}$ Graduate School of Infection Control Sciences, Kitasato University, Tokyo, Japan; ${ }^{5}$ Kitasato Institute for Life Sciences, Kitasato University, Tokyo, Japan and ${ }^{6}$ Department of Genetics, Faculty of Science, Kasetsart University, Bangkok, Thailand

Correspondence: Dr K Duangmal, Department of Microbiology, Faculty of Science, Kasetsart University, Chatuchak, Bangkok 10900, Thailand.

E-mail: fscikkd@ku.ac.th or kannikaduangmal@hotmail.com

Received 28 December 2011; revised 2 June 2012; accepted 15 June 2012; published online 11 July 2012 
soluble pigment were determined by comparing with the color chips from the Color Harmony Manual. ${ }^{14}$ The morphological characteristics were observed by light microscopy and scanning electron microscopy (SEM, JEOL-JSM 5600 LV; JEOL Ltd., Tokyo, Japan) of 15-day-old cultures grown on ISP medium 3. The utilization of a variety of substrates as sole carbon sources was tested using the basal inorganic nitrogen medium ${ }^{15}$ supplemented with a final concentration of $1 \%(\mathrm{v} / \mathrm{v})$ of the filter sterile-tested carbon sources. Catalase activity was determined with $3 \%(\mathrm{v} / \mathrm{v})$ hydrogen peroxide solution and oxidase activity was tested with $1 \%$ tetramethyl $p$-phenylenediamine dihydrochloride solution. Growth at various $\mathrm{pH}$ values and tolerance of $\mathrm{NaCl}$ were examined on ISP medium 2. The temperature range for growth was determined on ISP medium 2 using a temperature gradient incubator (Tokyo Kagaku Sangyo, Tokyo, Japan) with low and high temperatures between 5 and $50{ }^{\circ} \mathrm{C}$. Enzyme activity profiles were carried out using the API ZYM (bioMèrieux, Lyon, France) test kits. Melanin pigment was examined on ISP medium $7 .{ }^{13}$ Urease activity was determined by a color change on urea agar. ${ }^{15}$ The production of hydrogen sulfide was detected using lead acetate strips. Hydrolysis of casein, gelatin and nitrate reduction was examined following the methods of Gordon and Mihm. ${ }^{16}$ Micobispora mesophila JCM $3151^{\mathrm{T}}$ was used in this study for comparison.

Isolate $\mathrm{NN} 276^{\mathrm{T}}$ was examined for key chemical markers. The freeze-dried cells used for chemotaxonomic analysis were obtained from cultures grown in shake flasks of ISP medium 2 broth for 10 days at $27^{\circ} \mathrm{C}$. The isomers of diaminopimelic acid $\left(\mathrm{A}_{2} \mathrm{pm}\right)$ in the cell wall peptidoglycan and whole-cell sugar composition were determined by thin-layer chromatography as described by Staneck and Roberts. ${ }^{17}$ The acyl type of the cell wall was analyzed according to the method of Uchida and Aida. ${ }^{18}$ Polar lipids were examined using twodimensional thin-layer chromatography and identified by the method of Minnikin et al. ${ }^{19}$ Menaquinones were extracted and purified by the method of Collins et al., ${ }^{20}$ and isoprene units were subsequently analyzed by LC/MS (JMS-T100LP, JEOL) with PEGASIL ODS column $(2 ø \times 50 \mathrm{~mm}$; Senshu, Tokyo, Japan) using methanol/2-propanol (7:3). Mycolic acids were detected by thin-layer chromatography according to the method of Tomiyasu. ${ }^{21}$ Analysis of the fatty acids was performed according to the procedures of the Sherlock Microbial Identification System (MIDI, version 4.5; MIDI Inc., Newark, DE, USA) using a gas chromatograph (model HP6890; Hewlett Packard, Palo Alto, CA, USA) and identified with the ACTIN1 database.

Genomic DNA of the isolate NN276 ${ }^{\mathrm{T}}$ was extracted and purified from biomass according to the method of Kieser et al. ${ }^{22}$ The G $+\mathrm{C}$ content (mol\%) of the DNA was determined by HPLC according to the method of Tamaoka and Komagata. ${ }^{23}$ DNA-DNA relatedness was measured fluorometrically using the microplate hybridization method. ${ }^{24}$ The phylogenetic position of the isolate was determined based on 16S rRNA gene sequence. The 16S rDNA was amplified as described by Duangmal et al. ${ }^{25}$ and the PCR products were sequenced (First Base, Seri Kembangan, Malaysia) using universal primers. ${ }^{26}$ The resultant almost-complete 16S rRNA gene sequence, consisting of 1479 nucleotides, was aligned with the corresponding sequences of representatives of the genus Microbispora and of related genera in the family Streptosporangiaceae (retrieved from the GenBank databases) using the CLUSTAL X ${ }^{27}$ and PHYDIT programs (http://plaza.snu.ac.kr/ jchun/phydit/). Phylogenetic trees were inferred by the least-squares, ${ }^{28}$ maximum-parsimony ${ }^{29}$ and neighborjoining ${ }^{30}$ tree-making algorithms from the PHYLIP suite of programs ${ }^{31}$ and TREECON software. ${ }^{32}$ The resultant phylogenetic trees were viewed by TREEVIEW program. ${ }^{33}$

\section{RESULTS AND DISCUSSION}

Strain NN276 ${ }^{\mathrm{T}}$ was aerobic, Gram-positive, non-motile actinomycete, and produced branched and non-fragmented substrate mycelia. Single spherical spores with smooth surfaces were born on short sporophores (Figure 1), similar to those of M. mesophila. ${ }^{2}$ The results from chemical analysis indicated that strain NN276 ${ }^{\mathrm{T}}$ contained mesodiaminopimelic acid in the peptidoglycan. The major menaquinones were MK-9 $\left(\mathrm{H}_{4}\right)$, MK-9 $\left(\mathrm{H}_{2}\right)$ and MK-9. Glucose, madurose and ribose were detected as the components of sugars in the whole-cell hydrolysates. Polar lipid analysis showed that the organism

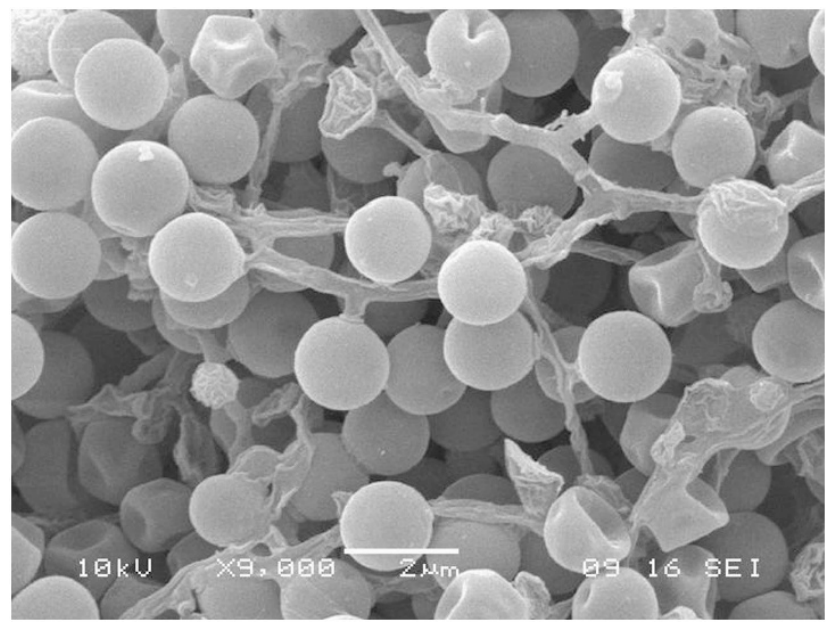

Figure 1 Scanning electron micrograph of spherical spores with smooth surfaces of strain NN276 ${ }^{\top}$ grown on ISP medium 3 for 15 days at $30^{\circ} \mathrm{C}$. Bar, $2 \mu \mathrm{m}$.

contained diphosphatidylglycerol, hydroxy-phosphatidylethanolamine, phosphatidylethanolamine, phosphatidylinositol, phosphatidylinositol mannoside and an unknown phosphoglycolipid. The cellular fatty acid profile was represented by the predominant of iso- $\mathrm{C}_{16: 0}(58.0 \%)$. Fatty acids found in smaller proportions included 10 methyl- $\mathrm{C}_{17}$ : 0 (11.2\%), unknown $16.048(7.0 \%)$, iso $\mathrm{H}-\mathrm{C}_{16: 1}$ (4.4\%), iso- $\mathrm{C}_{14: 0}$ (3.7\%), iso $2 \mathrm{OH}-\mathrm{C}_{16: 0}(2.8 \%)$, cis $9-\mathrm{C}_{17: 1}(2.4 \%), \mathrm{C}_{15: 0}(2.4 \%), 10$ methyl- $\mathrm{C}_{16: 0}(2.2 \%), \mathrm{C}_{18: 0}(1.8 \%)$, iso- $\mathrm{C}_{15: 0}(1.2 \%), \mathrm{C}_{17: 0}(0.8 \%)$, iso- $\mathrm{C}_{18: 0}(0.6 \%), \mathrm{C}_{16: 0}(0.4 \%)$, cis $9-\mathrm{C}_{16: 1}(0.4 \%)$, iso $\mathrm{F}_{-16: 1}(0.4 \%)$, iso- $\mathrm{C}_{12: 0}(0.2 \%)$ and $\mathrm{C}_{14: 0}(0.2 \%)$. The $\mathrm{G}+\mathrm{C}$ content was $70 \mathrm{~mol} \%$.

The almost-complete 16S rRNA gene sequence (1479 nt) of strain $\mathrm{NN} 276^{\mathrm{T}}$ was compared with sequences against the GenBank database. The results indicated that the isolate belongs to the genus Microbispora. The strain $\mathrm{NN}^{2} 26^{\mathrm{T}}$ showed the highest level of $16 \mathrm{~S}$ rRNA gene similarity with the type strain of $M$. mesophila $(97.9 \%$, a value corresponded to 31 nucleotide differences of 1456 locations). It is evident from the phylogenetic tree (Figure 2) that the strain NN276 ${ }^{\mathrm{T}}$ and the members of the genus Microbispora formed a coherent cluster that was supported by high bootstrap values and the strain $\mathrm{NN}_{2} 26^{\mathrm{T}}$ was clustered to M. mesophila in a well-separated branch with a high bootstrap value of $99 \%$ by neighbor-joining analysis. Similar tree topologies were obtained when the least-squares and maximumparsimony methods were applied. Determination of DNA-DNA relatedness studies were carried out between strain $\mathrm{NN}_{2} 26^{\mathrm{T}}$ and M. mesophila JCM $3151^{\mathrm{T}}$ by reciprocal hybridizations. The DNA-DNA reassociation value similarities were in the range of $45-49 \%$, confirming that the strain $\mathrm{NN} 276^{\mathrm{T}}$ represents a separate genomic species based on whole-genomic DNA relatedness of less than $70 \%$ cut-off point. ${ }^{34}$

From biochemical and physiological properties (Table 1), strain $\mathrm{NN} 276^{\mathrm{T}}$ was readily differentiated from its closest relatives, M. mesophila JCM $3151^{\mathrm{T}}$; in particular, the utilization of arabinose, $\mathrm{D}(+)$ mannose, $\mathrm{D}(-)$ ribose, $\mathrm{L}(-)$ fucose and $\mathrm{L}(-)$ rhamnose was negative in $\mathrm{NN} 276^{\mathrm{T}}$, properties that were positive in M. mesophila. The degradation of arbutin, casein, starch and xylan hydrolysis was positive in M. mesophila but negative in strain NN276 ${ }^{\mathrm{T}}$. Moreover, the strain $\mathrm{NN} 276^{\mathrm{T}}$ did not produce spore on ISP medium 2 and GYE agar, properties that were detected in M. mesophila JCM $3151^{\mathrm{T}}$. The temperature range for growth of the strain $\mathrm{NN} 276^{\mathrm{T}}$ was $16-40^{\circ} \mathrm{C}$, where as M. mesophila JCM $3151^{\mathrm{T}}$ was at $20-45^{\circ} \mathrm{C}$. 


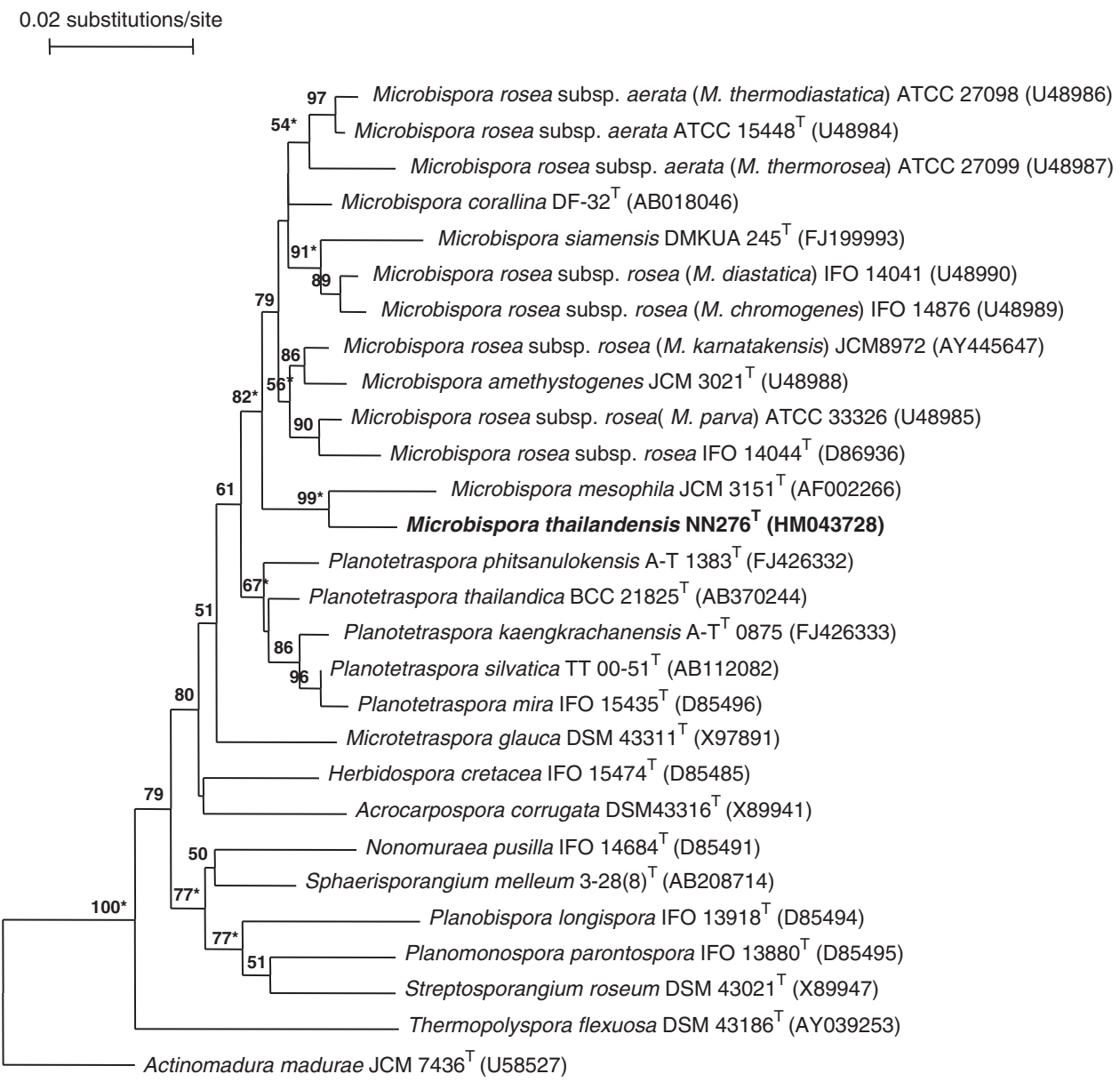

Figure 2 Neighbor-joining ${ }^{30}$ phylogenetic tree based on nearly complete 16S rRNA gene sequences showing the relation ship between the strain NN276 ${ }^{\top}$, species of the genus Microbispora and selected members of the family Streptosporangiaceae. Actinomadura madurae JCM 7436 ${ }^{\top}$ (U58527) was used as an outgroup. Asterisks indicate branches that were also found using the least-squares ${ }^{28}$ and maximum-parsimony ${ }^{29}$ tree-making algorithms. Numbers at the nodes indicate the percentage bootstrap support from an analysis of 1000 resampled data sets (only values $>50 \%$ are indicated). Bar, 0.02 substitutions/site.

It is interesting to note that both M. mesophila ${ }^{2}$ and isolate NN276 ${ }^{\mathrm{T}}$ are the only two species in the genus Microbispora that shared the same characteristic of single spherical spore formed on short sporophores. This unique single spore prompted a question whether these two species may represent a new genus. However, at present, we think it is premature to assume that they are a new genus based on only this observation. More isolates that shared this unique single spore are needed to help clarify its novel genus status.

It is apparent from this polyphasic study that the strain NN276 can be distinguished from representatives of members of the genus Microbispora. We proposed that strain $\mathrm{NN} 276^{\mathrm{T}}$ represents a novel species of Microbispora, because of which the name M. thailandensis sp. nov. is proposed.

\section{Description of $M$. thailandensis sp. nov.}

M. thailandensis (thai.lan.den'sis.) N.L. fem. adj. thailandensis pertains to Thailand, where the strain was originally isolated.

It is an aerobic, Gram-positive, non-motile actinomycete. Abundant pale-yellow substrate mycelia are well-developed on ISP medium 2 and GYE agar with light brown diffusible pigment. Poor growth with scantly whitish spores, without soluble pigments, is found on ISP media 3, 4 and 5. Melanin pigment is not observed. Single spherical spores with smooth surfaces are borne on short sporophores alternately branched from aerial mycelia. Good growth occurs between $26-38^{\circ} \mathrm{C}$. The $\mathrm{pH}$ range for growth is $5-9$ and cells can grow in the presence of $0-3 \% \mathrm{NaCl}(\mathrm{w} / \mathrm{v})$. Catalase, oxidase and nitrate reduction are positive. Urease and $\mathrm{H}_{2} \mathrm{~S}$ production are negative. Utilization of $\mathrm{D}(+)$ cellobiose, $\mathrm{D}(-)$ fructose, $\mathrm{D}(+)$ galactose, glucose, lactose, maltose, $\mathrm{D}(-)$ mannitol, raffinose, $\mathrm{D}(-)$ sorbitol and $\mathrm{D}(+)$ xylose is positive. Utilization of adonitol, arabinose, $\mathrm{L}(-)$ fucose, $\mathrm{D}(+)$ mannose, melibiose, $\mathrm{L}(-)$ rhamnose, $\mathrm{D}(-)$ ribose, sucrose and xylitol is negative. Gelatin, hypoxanthine, L-tyrosine and tween 40 are degraded. Aesculin, allantoin, arbutin, casein, cellulose, guanine, starch, xanthine and xylan are not degraded. Acid phosphatase, cystine aminopeptidase, esterase C4, $\alpha$-glucosidase, $\beta$-glucosidase, leucine, aminopeptidase, lipase $\mathrm{C} 8, \mathrm{~N}$-acetyl- $\beta$-glucosaminidase, phosphoamidase and valine aminopeptidase are detected with the API ZYM enzyme assay; alkaline phosphatase, chymotrypsin, $\alpha$-fucosidase, $\alpha$-galactosidase, $\beta$-galactosidase, $\beta$-glucuronidase, lipase C14, $\alpha$-mannosidase and trypsin are negative. The diagnostic diamino acid of the peptidoglycan is meso-diaminopimelic acid. Madurose is detected in whole-cell hydrolysates. The glycan moiety of the murein is acetylated. Major phospholipids were diphosphatidylglycerol, hydroxy-phosphatidylethanolamine, phosphatidylethanolamine, phosphatidylinositol and phosphatidylinositol mannoside. The major menaquinone is MK-9 $\left(\mathrm{H}_{4}\right)$, MK-9 $\left(\mathrm{H}_{2}\right)$ and MK-9. Mycolic acids are not detected. 
Table 1 Differential characteristics of strain $\mathrm{NN}^{276}{ }^{\top}$ and Microbispoa mesophila JCM $3151^{\top}$

\begin{tabular}{|c|c|c|}
\hline Characteristics & $N N 276^{T}$ & M. mesophila ${ }^{T}$ \\
\hline \multicolumn{3}{|l|}{ On ISP medium 2} \\
\hline Growth & Good & Good \\
\hline Sporulation & None & Good; light gray \\
\hline \multicolumn{3}{|l|}{ On ISP medium 3} \\
\hline Growth & Poor & Moderate \\
\hline Sporulation & Poor; white & Moderate; light gray \\
\hline \multicolumn{3}{|l|}{ Utilization of } \\
\hline Arabinose & - & + \\
\hline Maltose & + & - \\
\hline $\mathrm{D}(+)$ Mannose & - & + \\
\hline $\mathrm{D}(-)$ Ribose & - & + \\
\hline$\llcorner(-)$ Fucose & - & + \\
\hline L( -)Rhamnose & - & + \\
\hline \multicolumn{3}{|l|}{ Degradation of } \\
\hline Arbutin & - & + \\
\hline Casein & - & + \\
\hline Hypoxanthine & + & - \\
\hline L-Tyrosine & + & - \\
\hline Starch & - & + \\
\hline Xylan & - & + \\
\hline $\mathrm{NaCl}$ tolerance & $0-3 \%$ & $0-2 \%$ \\
\hline Growth at $\mathrm{pH} 10$ & - & + \\
\hline Temperature range & $16-40^{\circ} \mathrm{C}$ & $20-45^{\circ} \mathrm{C}$ \\
\hline
\end{tabular}

+ , positive; - , negative.

The major fatty acid in cellular fatty acids profile is iso- $\mathrm{C}_{16: 0}$. The $\mathrm{G}+\mathrm{C}$ content of the type strain DNA is $70 \mathrm{~mol} \%$.

The type strain, strain $\mathrm{NN}_{276^{\mathrm{T}}} \quad\left(=\mathrm{BCC} \quad 41490^{\mathrm{T}}=\mathrm{NRRL}\right.$ B- $24806^{\mathrm{T}}=$ NBRC $107569^{\mathrm{T}}$ ), was isolated from cave soil, Nakhon Sawan province, Thailand.

\section{ACKNOWLEDGEMENTS}

This work was supported by the Higher Education Research Promotion and National Research University Project of Thailand, Office of the Higher Education Commission and Kasetsart University Research and Development Institute. We thank Professor JP Euzéby for his kind advice on naming the species.

Accession number: The GenBank accession number for the $16 \mathrm{~S}$ rRNA gene sequence of strain $\mathrm{NN}_{2} 26^{\mathrm{T}}$ is HM043728.

1 Nonomura, H. \& Ohara, Y. Distribution of actinomycetes in soil. II. Microbispora, a new genus of the Streptomycetaceae. J. Ferment. Technol. 35, 307-311 (1957).

2 Zhang, Z., Wang, Y. \& Ruan, J. Reclassification of Thermomonospora and Microbispora. Int. J. Syst. Bacteriol. 48, 411-422 (1998).

3 Miyadoh, S., Amano, S., Tohyama, H. \& Shomura, T. A taxonomic review of the genus Microbispora and a proposal to transfer two species to the genus Actinomadura and to combine ten species into Microbispora rosea. J. Gen. Microbiol. 136, 1905-1913 (1990).

4 Boondaeng, A., Ishida, Y., Tamura, T., Tokuyama, S. \& Kitpreechavanich, V. Microbispora siamensis sp. nov., a thermotolerant actinomycete isolated from soil. Int. J. Syst. Evol. Microbiol. 59, 3136-3139 (2009).
5 Nakajima, Y., Kitpreechavanich, V., Suzuki, K. \& Kudo, T. Microbispora corallina sp. nov., a new species of the genus Microbispora isolated from Thai soil. Int. J. Syst. Bacteriol. 49, 1761-1767 (1999).

6 Nonomura, H. \& Ohara, Y. Distribution of actinomycetes in soil. X. New genus and species of monosporic actinomycetes. J. Ferment. Technol. 49, 895-903 (1971).

7 Stackebrandt, E., Rainey, F. A. \& Ward-Rainey, N. L. Proposal for a new hierarchic classification system, Actinobacteria classis nov. Int. J. Syst. Bacteriol. 47, 479-491 (1997).

8 Ara, I. \& Kudo, T. Sphaerosporangium gen. nov., a new member of the family Streptosporangiaceae, with descriptions of three new species as Sphaerosporangium melleum sp. nov., Sphaerosporangium rubeum sp. nov. and Sphaerosporangium cinnabarinum sp. nov., and transfer of Streptosporangium viridialbum Nonomura and Ohara 1960 to Sphaerosporangium viridialbum comb. nov.. Actinomycetologica 21, 11-21 (2007).

9 Zhi, X. -Y., Li, W. -J. \& Stackebrandt, E. An update of the structure and 16S rRNA gene sequence-based definition of higher ranks of the class Actinobacteria, with the proposal of two new suborders and four new families and emended descriptions of the existing higher taxa. Int. J. Syst. Evol. Microbiol. 59, 589-608 (2009)

10 Bulina, T. I., Alferova, I. V. \& Terekhova, L. P. A novel approach to isolation of actinomycetes involving irradiation of soil samples with microwaves. Microbiology 66 , 278-282 (1997).

11 Hayakawa, M. \& Nonomura, H. Humic acid-vitamin agar, a new medium for selective isolation of soil actinomycetes. J. Ferment. Technol. 65, 501-509 (1987).

12 Gordon, R. E. \& Mihm, J. M. Identification of Nocardia caviae (Erikson) nov. comb. Ann. N.Y. Acad. Sci. 98, 628-636 (1962).

13 Shirling, E. B. \& Gottlieb, D. Methods for characterization of Streptomyces species. Int J. Syst. Bacteriol. 16, 313-340 (1966).

14 Jacobson, E., Grauville, W. C. \& Fogs, C. E. Color Harmony Manual. 4th edn. (Container Corporation of America, Chicago, IL, 1958).

15 Gordon, R. E., Barnett, D. A., Handerhan, J. E. \& Pang, C. H. -N. Nocardia coeliaca, Nocardia autotrophica, and the nocardin strain. Int. J. Syst. Bacteriol. 24, 54-63 (1974)

16 Gordon, R. E. \& Mihm, J. M. A comparative study of some strains received as nocardiae. J. Bacteriol. 73, 15-27 (1957).

17 Staneck., J. L. \& Roberts, G. D. Simplified approach to identification of aerobic actinomycetes by thin-layer chromatography. App. Microbiol. 28, 226-231 (1974)

18 Uchida, K. \& Aida, K. An improved method for the glycolate test for simple identification of the acyl type of bacterial cell walls. J. Gen. Appl. Microbiol. 30, 131-134 (1984).

19 Minnikin, D. E., Patel, P. V., Alshamaony, L. \& Goodfellow, M. Polar lipid composition in the classification of Nocardia and related bacteria. Int. J. Syst. Bacteriol. 27, 104-117 (1977).

20 Collins, M. D., Pirouz, T., Goodfellow, M. \& Minnikin, D. E. Distribution of menaquinones in actinomycetes and corynebacteria. J. Gen. Microbiol. 100, 221-230 (1977).

21 Tomiyasu, I. Mycolic acid composition and thermally adaptative changes in Nocardia asteroides. J. Bacteriol. 151, 828-837 (1982).

22 Kieser, T., Bibb, M. J., Buttner, M. J., Chater, K. F. \& Hopwood, D. A. Practical Streptomyces Genetics (John Innes Foundation, Norwich, 2000).

23 Tamaoka, J. \& Komagata, K. Determination of DNA base composition by reversedphase high-performance liquid chromatography. FEMS Microbiol. Lett. 25, 125-128 (1984).

24 Ezaki, T., Hashimoto, Y. \& Yabuuchi, E. Fluorometric deoxyribonucleic acid-deoxyribonucleic acid hybridization in microdilution wells as an alternative to membrane filter hybridization in which radioisotopes are used to determine genetic relatedness among bacterial strains. Int. J. Syst. Bacteriol. 39, 224-229 (1989).

25 Duangmal, K., Ward, A. C. \& Goodfellow, M. Selective isolation of members of the Streptomyces violaceoruber clade from soil. FEMS Microbiol. Lett. 245, 321-327 (2005).

26 Lane, D. J. 16S/23S rRNA sequencing in Nucleic Acid Techniques in Bacterial Systematics. Stackebrandt, E. \& Goodfellow, M. (eds) 115-148 (John Wiley \& Sons, Chichester, 1991)

27 Thompson, J. D., Gibson, T. J., Plewniak, F., Jeanmougin, F. \& Higgins, D. G. The CLUSTAL $X$ windows interface: flexible strategies for multiple sequence alignment aided by quality analysis tools. Nucleic Acids Res. 25, 4876-4882 (1997).

28 Fitch, W. M. \& Margoliash, E. Construction of phylogenetic trees: a method based on mutation distances as estimated from cytochrome $c$ sequences is of general applicability. Science 155, 279-284 (1967).

29 Kluge, A. G. \& Farris, F. G. Quantitative phyletics and the evolution of anurans. Syst Zool. 18, 1-32 (1969).

30 Saitou, N. \& Nei, M. The neighbour-joining method: a new method for reconstructing phylogenetic trees. Mol. Biol. Evol. 4, 406-425 (1987).

31 Felsenstein, J. PHYLIP (Phylogenetic Inference Package) Version 3.5c. Distributed by the author. (University of Washington, Seattle, WA, 1993).

32 Van de Peer, Y. \& De Wachter, R. TREECON for Windows: a software package for the construction and drawing of evolutionary trees for the Microsoft Windows Environment. Comp. Appl. Biosci. 10, 569-570 (1994).

33 Page, R. D. M. TreeView: an application to display phylogenetic trees on personal computers. Comput. Appl. Biosci. 12, 357-358 (1996).

34 Wayne, L. G. et al. International Committee on Systematic Bacteriology. Report of the ad hoc committee on the reconciliation of approaches to bacterial systematics. Int. J. Syst. Bacteriol 37, 463-464 (1987). 